\title{
PERANCANGAN SONGKOK GURU KABUPATEN TAKALAR
}

\author{
Mustakim, Aswar, Nurabdiansyah \\ Fakultas Seni dan Desain Universitas Negeri Makassar \\ aswar_saini@yahoo.co.id \\ nurabdiansyah@unm.ac.id
}

\begin{abstract}
Abstrak
Songkok guru merupakan produk anyaman traditional khas Kabupaten Takalar khususnya di desa Bontokassi Kecamatan Galesong Selatan. Permasalahan yang terjadi pada produk tersebut adalah tidak memiliki kemasan pada saat produk dijual/didistribusikan. Hal itulah yang mendasari perancangan kemasan ini, bertujuan untuk menghasilkan kemasan yang berguna bagi pengrajin dan memiliki nilai jual yang lebih dari sebelumnya karna proses pengerjaan produk yang cukup lama dengan penuh ketelitian. Kemasan ini dilandasi dengan konsep maskulin dan nature. Karena maskulin menunjukkan sifat laki-laki (gagah, kekar, lebih berfikir secara logika daripada perasaan) seperti yang kita ketahui bahwa songkok guru ini hanya digunakan oleh pria dewasa diantaranya oleh para bangsawan yang memiliki derajat tinggi. Sedangkan nature artinya alam dimana bahan produk songkok guru yang digunakan dari serat pelepah pohon lontar (dari alam) dan juga nantinya akan menggunakan bahan kemasan dari daun lontar. Dari konsep itu diharapkan penulis dapat menciptakan kemasan yang efektif dan berguna bagi pengrajin. Manfaat perancangan ini yaitu sebagai bentuk strategi yang efektif untuk menambah minat konsumen terhadap produk songkok guru serta memiliki harga jual yang lebih tinggi dari sebelumnya. Selain itu, untuk menjaga kualitas produk pada saat dibeli oleh konsumen dibeli atau pada saat didistribusikan.
\end{abstract}

Kata kunci: songkok guru, tradisional, kemasan.

\begin{abstract}
Abstrak
Songkok guru is a traditional wicker products typical of Takalar Regency especially in Bontokassi village, South Galesong District. The problem with the product is that it has no packaging when the product is sold / distributed. That's what underlies the design of this packaging, aims to produce useful packaging for craftsmen and has more selling value than before because the process of product long enough with full accuracy. This package is based on the concept of masculine and nature. Because masculine shows the nature of man (handsome, stocky, more logical rather than feeling) as we know that songkok guru is only used by adult men among them by the nobles who have a high degree. While nature means nature where the material of songkok guru product used from palm leaf fiber (from nature) and also later will use the packaging material from palm leaves. From the concept it is expected that the author can create an effective and useful packaging for craftsmen. The benefits of this design is as an effective form of strategy to increase consumer interest in the product songkok guru and has a higher selling price than before. In addition, to maintain product quality when purchased by consumers purchased or at the time of distribution.
\end{abstract}

Keywords: Songkok guru, traditional, packaging

\section{PENDAHULUAN}

Kreativitas serta inovasi dari anak-anak bangsa bisa menciptakan produk kerajinan yang unggul serta berkembang mengikuti kebutuhan serta perkembangan teknologi terkini. Bahan alam sebagai salah satu bahan dasar untuk membuat suatu kerajinan banyak tersedia di berbagai daerah di Indonesia. Sehingga produk-produk kerajinan yang dihasilkan pun sangat beraneka ragam dan 
memiliki ciri khas tersendiri disetiap daerahnya. Kerajinan bahan alam adalah suatu kerajinan yang dibuat dari bahan dasar yang telah disediakan oleh alam seperti bambu, serat alam, rotan.

Pengrajin anyaman serat lontar di Desa Bonto Kassi, Kecamatan Galesong Selatan, Kabupaten Takalar, terdapat banyak pengrajin yang terbagi menjadi beberapa kelompok desa salah satunya kelompok Melati yang diketuai oleh Ibu Silvia. Kelompok ini merupakan industri rumahan dan tidak memiliki toko. Pengrajin rata-rata ibu rumah tangga dengan memanfaatkan pohon lontar sebagai bahan baku membuat hasil kerajinan tangan seperti songkok guru, kopiah atau songkok yang bentuknya sama seperti 4 peci pada umumnya namun tetap berbahan serat lontar dan kerajinan lainnya seperti anyaman serat lontar. Pengrajin ibu-ibu ini sangat kreatif karna memiliki banyak motif songkok guru dan kopiah jadi itu merupakan salah satu daya tarik bagi konsumen.

Produk anyaman serat lontar ini juga merupakan produk unggulan khususnya di Desa Bontokasi Kabupaten Takalar dan terkhusus songkok guru yang merupakan pakaian (penutup kepala) adat pada saat diadakan upacara adat dan juga pesta-pesta perkawinan orang Sulawesi Selatan.

Pemasaran songkok guru ini dijual diberbagai Toko oleh-oleh khas Makassar seperti di Benteng Somba Opu. Pemasarannya sudah terbilang cukup bagus karena sudah sampai di luar negeri seperti Malaysia, salah satu cara pemasarannya yaitu mengikutkan setiap ada event pameran dan sudah sering masuk acara Tv lokal. Namun yang menjadi kendala atau keluhan konsumen karena produk ini belum memiliki kemasan sehingga gampang rusak pada saat dibeli apalagi dalam pembelian dengan jumlah banyak. Selain itu, produk ini mudah jamuran jika terkena air. Minimnya sarana dan prasarana yang dimiliki oleh industri rumahan ini menjadi salah satu faktor yang menyebabkan tidak menggunakan kemasan.

Kemasan merupakan hal yang penting, karena kemasan yang menarik dapat memikat para pelanggan untuk membeli sebuah produk di pasaran. Maka timbulah inisiatif untuk mengangkat produk tersebut dengan memperbaiki kelemahan pada aspek kemasan, guna memberikan identitas produk bagi pihak produsen dan konsumen juga untuk mengukuhkan bahwa produk ini diproduksi oleh kelompok Melati desa Bontokassi sehingga pengrajin atau industri yang lain tidak dapat mengklaim hasil produksi ini, diharapkan dengan tampilan kemasan yang baru produk ini dapat diunggulkan.

Sebagai seorang desainer komunikasi visual, hal ini merupakan suatu tantangan karena selain dituntut untuk dapat menyajikan sebuah (desain) kemasan yang estetis, juga dituntut untuk memaksimalkan daya tarik kemasan agar dapat menarik konsumen dalam pertarungan untuk menghadapi produk-produk pesaing. Tantangan yang lain adalah klien tidak hanya mengharapkan peningkatan penjualan tetapi juga agar konsumen tetap setia menggunakan produk tersebut.

Perancangan kemasan ini bertujuan untuk : (1) Merancang kemasan yang komunikatif dan menarik agar konsumen lebih tertarik (2) Merancang dan membuat kemasan yang disesuaikan dengan target audiencenya, sehingga dapat secara tepat mencapai target sasaran. (3) Memvisualisasikan ide dan kreasi dalam bentuk desain kemasan "songkok guru" sebagai bentuk karya komunikasi visual. (4) Agar harga jualnya lebih tinggi dibandingkan sebelumnya.

Dalam perancangan kemasan pembelajaran ini, diharapkan akan memberi manfaat yaitu sebagai berikut : (1) Manfaat bagi penulis, diharapkan dapat berfikir kreatif dalam permbuatan kemasan ini agar bisa mencapai tujuan perancangan (2) Manfaat bagi pengrajin, sebagai identifikasi penjual dan sebagai bentuk strategi yang efektif untuk 
menambah minat konsumen terhadap produk tersebut serta memiliki harga jual yang lebih tinggi dari sebelumnya. (3) Manfaat bagi konsumen, perancangan desain kemasan ini untuk menjaga kualitas produk yang dibeli atau pada saat didistribusikan.

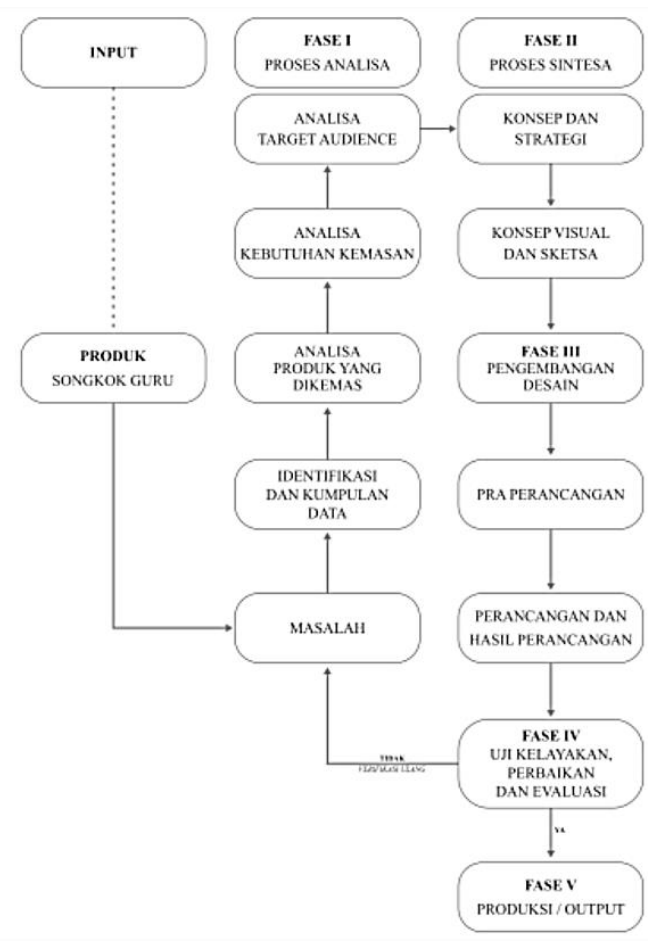

Gambar 1.1 Bagan Skema Perancangan

Kemasan telah dikenal sejak jaman manusia purba. Orang- orang primitif menggunakan kulit binatang dan keranjang rumput untuk mewadahi buah-buahan yang dipungut dari hutan. Kemudian 8.000 tahun yang lalu, bangsa Cina membuat aneka ragam keramik untuk mewadahi benda padat ataupun cair. Orang-orang Indonesia kuno membuat wadah dari bambu untuk menyimpan benda cair. Menjelang abad pertengahan, bahanbahan kemasan terbuat dari kulit, kain, kayu, batu, keramik dan kaca.

Selama berabad-abad, fungsi sebuah kemasan hanyalah sebatas untuk melindungi barang atau mempermudah barang untuk dibawa. Seiring dengan perkembangan jaman yang semakin kompleks, barulah terjadi penambahan nilai-nilai fungsional dan peranan kemasan dalam pemasaran mulai diakui sebagai satu kekuatan utama dalam persaingan pasar.

Sebenarnya peranan kemasan baru dirasakan pada tahun 1950-an, saat banyak munculnya supermarket atau pasar swalayan, di mana kemasan harus "dapat menjual" produk-produk di rak-rak toko. Tetapi pada saat itupun 9 kemasan hanya berfungsi memberikan informasi - memberitahu kepada konsumen tentang apa isi atau kandungan di dalam kemasan tersebut. Baru pada tahun 1980-an di mana persaingan dalam dunia usaha semakin tajam dan kalangan produsen saling berlomba untuk merebut perhatian calon konsumen, bentuk dan model kemasan dirasakan sangat penting peranannya dalam strategi pemasaran. Di sini kemasan harus mampu menarik perhatian, menggambarkan keistimewaan produk, dan "membujuk" konsumen. Pada saat inilah kemasan mengambil alih tugas penjualan pada saat jual beli terjadi.

Kemasan merupakan faktor penting dalam sebuah usaha produksi karena fungsi dan peranannya dalam bidang pemasaran, baik produk berupa olahan makanan (pangan) maupun barang kebutuhan sehari-hari (consumer goods) : (1) Fungsi Praktis, Secara umum fungsi praktis kemasan, baik bagi barang/produk makanan maupun kebutuhan sehari-hari (consumer goods), dapat dirinci sebagai berikut : (a) Mewadahi produk selama pendistribusian. (b) Melindungi dan Menjaga Kualitas (mengawetkan produk). (c) Meningkatkan Efisiensi. (2) Fungsi Promosi/ Simbolik/Estetis dapat dirincikan sebagai berikut : (a) Fungsi promosi, kemasan dapat digunakan sebagai alat komunikasi dam informasi kepada konsumen melalui label yang terdapat dalam kemasan. Kemasan merupakan sarana informasi dan promosi bagi produk yang dikemasnya. (b) Fungsi simbolik, sebagai identitas produk, penanda pengenal barang/produk yang dikemasnya dan juga bagi perusahaan yang memproduknya. (c) Fungsi estetik, sebagai daya tarik calon pembeli dan menambah estetika dan nilai jual. 
Menurut Julianti dan Nurminah (2006), kemasan dalam diklasifikasikan berdasarkan : (1) Klasifikasi kemasan berdasarkan frekuensi pemakaian : (a) Kemasan sekali pakai (disposable), yaitu kemasan yang langsung dibuang setelah dipakai. (b) Kemasan yang dapat dipakai berulangkali (multitrip) dan biasanya dikembalikan ke produsen. (c) Kemasan atau wadah yang tidak dibuang atau dikembalikan oleh konsumen (semi disposable), tapi digunakan untuk kepentingan lain oleh konsumen. (2) Klasifikasi kemasan berdasarkan struktur sistem kemas : (a) Kemasan Primer, yaitu kemasan yang langsung bersentuhan dengan produk yang di bungkusnya. (b) Kemasan sekunder, yang tidak bersentuhan langsung dengan produknya akan tetapi membungkus produk yang telah dikemas dengan kemasan primer. (c) Kemasan tersier dan kuartener yaitu kemasan untuk mengemas setelah kemasan primer atau sekunder. (3) Klasifikasi Kemasan Berdasarkan Sifat kekakuan bahan kemasan : (a) Kemasan fleksibel yaitu bahan kemasan yang mudah dilenturkan tanpa adanya retak atau patah (b) Kemasan kaku yaitu bahan kemas yang bersifat keras, kaku, tidak tahan lenturan, patah bila dibengkokkan relatif lebih tebal dari kemasan fleksibel. (c) Kemasan semi kaku/semi fleksibel yaitu bahan kemas yang memilki sifat-sifat antara kemasan fleksibel dan kemasan kaku. (4) Klasifikasi Kemasan Berdasarkan Sifat perlindungan terhadap lingkungan : (a) Kemasan hermetis (tahap uap dan gas) yaitu kemasan yang secara sempurna tidak dapat dilalui oleh gas, udara atau uap air sehingga selama masih hermetis wadah ini tidak dapat dilalui oleh bakteri, kapang, ragi, dan debu. (b) Kemasan tahan cahaya yaitu wadah yang tidak bersifat transparan, misalnya kemasan logam, kertas dan foil. (c) Kemasan tahan suhu tinggi, yaitu kemasan untuk bahan yang memerlukan proses pemanasan, pasteurisasi dan sterilisasi. (5) Klasifikasi Kemasan Berdasarkan Tingkat kesiapan pakai
: (a) Wadah siap pakai yaitu bahan kemasan yang siap untuk diisi dengan bentuk yang telah sempurna. (b) Wadah siap dirakit/wadah lipatan yaitu kemasan yang masih memerlukan tahap perakitan sebelum diisi.

Kemasan yang baik dan akan digunakan semaksimal mungkin dalam pasar harus mempertimbangkan dan dapat menampilkan beberapa faktor, antara lain sebagai berikut : Faktor pengamanan, ekonomi, pendistribusian, komunikasi, ergonomi, estetika, identitas, promosi dan lingkungan.

Kunci utama untuk membuat sebuah desain kemasan yang baik adalah kemasan tersebut harus simple (sederhana), fungsional dan menciptakan respons emosional positif yang secara tidak langsung "berkata", "Belilah saya."

Menurut penelitian, dari seluruh kegiatan penginderaan manusia, $80 \%$ adalah penginderaan melalui penglihatan atau kasatmata (visual). Karena itulah, unsur-unsur grafis dari kemasan antara lain: warna, bentuk, merek, ilustrasi, huruf dan tata letak merupakan unsur visual yang mempunyai peran terbesar dalam proses penyampaian pesan secara kasatmata (visual communication).

Agar berhasil, maka penampilan sebuah kemasan harus mempunyai daya tarik. Daya tarik pada kemasan dapat digolongkan menjadi dua, yaitu daya tarik visual (estetika) dan daya tarik praktis (fungsional).

Sebagai salah satu bentuk komunikasi, industri kemasan menempatkan proses desain komunikasi visual dalam posisi penting, yaitu kamampuan menarik perhatian, menjaga perubahan trend pasar yang senantiasa berlangsung dan menyadari akan perkembangan teknologi dan bahan kemasan. Desain komunikasi visual merupakan bagian yang integral dalam mendesain suatu kemasan untuk menjual produk juga membuat kemasan menjadi lebih jelas dan informatif bagi pembeli. Berikut adalah aspek dkv dalam 
kemasan yang perlu diperhatikan : (1) Penggunaan logo dan merek dagang pada desain kemasan, logo dan merek dagang dalam kemasan merupakan identitas utama dari produk untuk dapat dikenali konsumen. (2) Pendekatan warna dalam desain kemasan, warna merupakan perangsang indra yang sangat penting dalam kemasan untuk dapat menciptakan daya tarik visual. (3) Pendekatan bentuk dalam desain kemasan, bentuk merupakan bagian dari desain.bentuk kemasan tetap ditekankan pada kebutuhan pemasaran sebagai preferensinya dibandingkan pertimbangan visual murni. (4) Pemanfaatan tipografi dalam desain kemasan, huruf dapat memberikan penekanan makna dari sebuah brand name atau logotype. Sebuah kesan mengenai produk dapat dibangun melalui desain logotype yang kuat. (5) Ilustrasi gambar pada label kemasan, gambar dan simbol dapat menarik perhatian dan mengarahkan perhatian pembeli agar mengingatnya selama mungkin, dengan penggunaan bahasa yang umum yang dengan cepat dapat dimengerti oleh setiap orang. (6) Desain kemasan sebagai media promosi, Menurut Marc Gobe dalam bukunya Emotional Branding (2003), kemasan adalah iklan setengah detik. Kemasan harus dapat menarik perhatian Anda dalam watu yang singkat dan membangun familiaritas terhadap produk.

Dalam proses mendesain kemasan, salah satu komponen penting yang perlu dipertimbangkan secara cermat adalah memilih dan menentukan bahan yang akan digunakan bagi sebuah produk tertentu.

Pengelompokan jenis bahan kemasan berdasarkan klasifikasi kemasan, secara garis besarnya dapat dibagi menjadi 2 bagian, yaitu sebagai berikut : (1) Untuk wadah utama, biasa disebut sebagai kemasan primer, dimana bahan kemasan terjadi kontak/berhubungan langsung dengan bahan pangan. Bahan untuk kemasan primer tersebut, antara lain : kertas, gelas, logam, plastik, kain, kulit, daun, gerabah, bambu, dan lain-lain. (2) Untuk wadah luar, biasa disebut sebagai kemasan sekunder, tesier dan kuartener. Berfumgsi sebagai pelindung wadah utama selama distribusi, penjualan, atau penyimpanan. Bahan wadah luar tersebut, antara lain : kayu, bambu, dan karton.

Pada prinsipnya, bentuk kemasan sangatlah tergantung dari bahan yang digunakan untuk membuat kemasan tersebut. Ketergantungan ini disebabkan karena setiap jenis bahan yang digunakan memiliki karakteristik masing-masing. Ada jenis bahan tertentu yang tidak dapat begitu saja dibentuk sesuai kehendak kita, karena kendala teknologi dan cara yang efisien untuk mengerjakannya atau membentuknya sesuai keinginan kita.

Pada dasarnya, bentuk kemasan dapat diwujudkan sangat tergantung dari sifat dan jenis bahan dasar yang digunakan. Bentukbentuk 36 kemasan dapat digolongkan lagi berdasarkan kemasan yang digunakan, antara lain : (1) kayu, yaitu : nailed box, wire bound box, crate, basket dan barrel ; (2) Logam : Drum, pail, kaleng logam dan colapsible tube; dan (3) gelas : bottle, jar, timbler, jug, carboy, vial dan ampul (rahmawati, 2013).

Untuk bersaing secara lebih aktif, sekarang banyak perusahaan menerapkan pemasaran sasaran pada 'segmen konsumen' tertentu saja. Perusahaan lebih memfokuskan diri pada konsumen yang mempunyai peluang terbesar untuk mereka ouaskan. Menurut Kotler (2005), selurh stategi pemasaran harus dibangun berdasarkan tiga langkah utama dalam menentukan sasaran pemasaran yaitu:

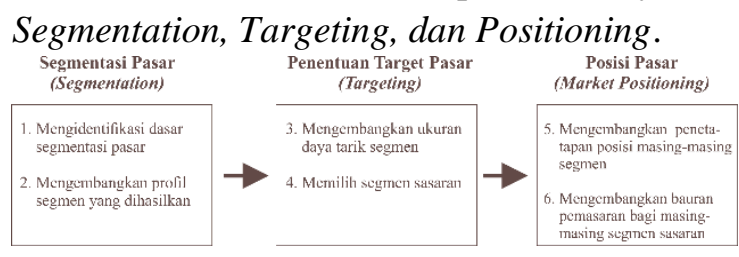

Gambar 1.2 Skema tiga langkah utama sasaran dalam pemasaran (sumber: Kotler, Bowen, dan Makens.2002)

Sasaran/target pemasaran yang efektif mengharuskan pemasar/produsen 
Mengidentifikasi dan menentukan profil berbagai kelompok pembeli yang mempunyai kebutuhan dan preferensi berbeda (segmentasi pasar). (2) Memilih satu atau lebih segmen pasar (penentuan sasaran/target pasar). (3) Untuk setiap segmen sasaran, menentukan dan mengkomunikasikan berbagai manfaat penawaran pasar perusahaan (positioning pasar).

Kemasan dapat didefinisikan sebagai seluruh kegiatan merancang dan memproduksi wadah atau bungkus atau kemasan suatu produk. Kemasan meliputi tiga hal, yaitu merek, kemasan itu sendiri dan label. Ada tiga alasan utama untuk melakukan pembungkusan, yaitu : (1) Kemasan memenuhi syarat keamanan dan kemanfaatan. Kemasan melindungi produk dalam perjalanannya dari produsen ke konsumen. (2) Kemasan dapat melaksanakan program pemasaran. Melalui kemasan identifikasi produk menjadi lebih efektif dan dengan sendirinya mencegah pertukaran oleh produk pesaing. Kemasan merupakan satusatunya cara perusahaan membedakan produknya. (3) Kemasan merupakan suatu cara untuk meningkatkan laba perusahaan. Oleh karena itu perusahaan harus membuat kemasan semenarik mungkin. Dengan kemasan yang sangat menarik diharapkan dapat memikat dan menarik perhatian konsumen. Selain itu, kemasan juga dapat mangurangi kemungkinan kerusakan barang dan kemudahan dalam pengiriman.

Pohon Lontar atau Tal atau Siwalan merupakan jenis tanaman Palma yang tumbuh di Asia Selatan dan Asia Tenggara. Ciri khas pohon Lontar ini adalah kokoh dan kuat serta bisa bertahan hingga 25 tahunan. Berbatang tunggal dan bisa mencapai ketinggian 15-30 meter dan mempunyai diameter batang sekitar $60 \mathrm{~cm}$. terkadang batangnya tumbuh adapula yang sendirisendiri, berkelompok dan berdekat-dekatan. Mempunyai ciri-ciri pada daun yang besar, dan terkumpul di ujung batang serta membentuk tajuk yang membulat. Helaian daunnya menyerupai kipas, berbentuk bundar dan mempunyai diameter sekitar 1,55 meter.

Anyaman serat lontar merupakan anyaman yang dibuat dengan menggunakan bahan baku pelepah daun lontar yang diolah melalui proses yang cukup lama. Serat lontar sebagai bahan dasar produk anyaman berasal dari pohon lontar. Pohon lontar itu sendiri tidak bisa ditemukan di seluruh wilayah Indonesia. Pohon lontar hanya bisa ditemukan di beberapa daerah di Sulawesi Selatan yaitu Kabupaten Takalar, Kabupaten Gowa, dan Kabupaten Jeneponto.

Keterampilan anyaman serat lontar merupakan suatu keterampilan yang telah dimiliki oleh masyarakat di Desa Bontokassi sejak dari zaman Kerajaan Galesong sekitar abad XIX, dimana pada zaman kerajaan tersebut para bangsawan menggunakan suatu jenis kopiah yang disebut "songkok guru" sebagai aksesoris dikepala.

Produk anyaman serat lontar saat ini sudah bervariasi, hal ini disesuaikan dengan kebutuhan pasar. Seiring dengan perkembangan tuntutan para penggemar produk anyaman serat lontar, pengrajin anyaman serat lontar telah mengembangkan berbagai variasi model berasarkan tuntutan dari para pelanggan.

Terdapat beberapa kerajinan yang telah dihasilkan oleh anyaman serat lontar, yaitu : Songkok guru, Songkok Haji, Songkok Gudang, asbak, Guci, Kipas, Gantungan kunci, Gelang, Luaran bantal kursi, Lampu kamar, dan masih banyak lagi.

Songkok guru atau peci tradisional khas suku Makassar, kulturnya telah menjadi penutup kepala yang "wajib" bagi lelaki asli Makassar dalam setiap acara adat. Namun, pemakaian songkok itu telah meluas dan kerap digunakan dalam acara-acara formal selain adat. Bentuknya bundar dan kaku karena terbuat dari serat pelepah lontar.

Awal mula penggunaan songkok guru ini dipakai oleh Anrong Guru atau panrita kerajaan Gowa pada saat mengislamkan semua 


\section{imajinaasi}

kerajaan-kerajaan bugis termasuk Bone di zaman Raja Gowa Sultan Alauddin. Dimana yang memakai songkok guru ini adalah guruguru besar besar/raja sehingga dinamakan songkok guru. Namun songkok guru memiliki nama lain yaitu songkok Pamiring yang lazimnya nama songkok ini digunakan oleh orang-orang bugis, juga dikenal dengan nama songkok Recca dan songkok To Bone. Selain songkok Pamiring ada juga nama songkok Nibiring Bulaeng yang artinya songkok yang dikelilingi oleh emas (dililit). Namun pada umumnya semua songkok ini memiliki bentuk yang sama hanya nama yang membedakannya di setiap daerah seperti Bugis dan Makasssar.

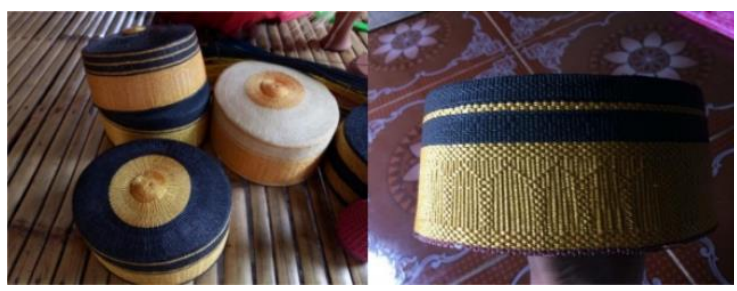

Gambar 1.3 Produk songkok guru (sumber: Dokumentasi pribadi, Februari 2017)

\section{Ukuran Songkok Guru}

\begin{tabular}{|c|c|c|}
\hline Nomor Songkok & Ukuran Lingkaran Kepala & Tinggi Songkok \\
\hline 5 & $55 \mathrm{~cm}$ & $7 \mathrm{~cm}$ \\
\hline 6 & $56 \mathrm{~cm}$ & $7 \mathrm{~cm}$ \\
\hline 7 & $57 \mathrm{~cm}$ & $7 \mathrm{~cm}$ \\
\hline 8 & $58 \mathrm{~cm}$ & $7 \mathrm{~cm}$ \\
\hline 9 & $59 \mathrm{~cm}$ & $7 \mathrm{~cm}$ \\
\hline 10 & $60 \mathrm{~cm}$ & $7 \mathrm{~cm}$ \\
\hline 11 & $61 \mathrm{~cm}$ & $7 \mathrm{~cm}$ \\
\hline
\end{tabular}

Tabel 2.1 Ukuran Songkok Guru

Strategi pemasaran songkok guru dan berbagai produk anyaman lainnya dilakukan melalui pameran-pameran yang berskala lokal ditingkat kabupaten dan berskala nasional melalui pameran khas Indonesia dijakarta. Pemasaran ini tidak Hanya melalui pameran, tetapi pengrajipun sudah ada yang memasarkaan produknya melalui BlackBerry Massanger (BBM) atau social media seperti Facebook, Instagram, line, WhatsApp, dan sebagainya.
Selain itu biasanya kelompok pengrajin juga menerima orderan pembuatan dan dibuat di rumah masing-masing. Hasil produksi juga dipasarkan ke berbagai toko oleh-oleh di Makassar dan Bandara Sultan Hasanuddin.

Peci/kopiah sangat sering kita temukan dimana-mana yang sering orang gunakan pada saat beribadah bahkan pada acara adat. Peci ini memiliki banyak bentuk dan motif. Tetapi dari segi kemasan hampir semua berbentuk persegi panjang, berbahan kertas seperti kertas karton dan yang membedakan hanya dari segi visualnya saja. Tampilan visual dari segi warna dan ilustrasi sangat biasa saja sehingga kurang menarik minat konsumen untuk membeli.

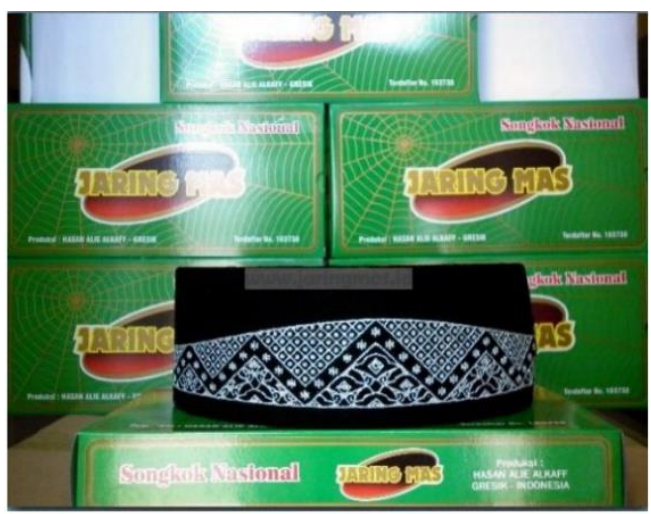

Gambar 1.4 Peci Jaring Mas (Sumber: Internet)

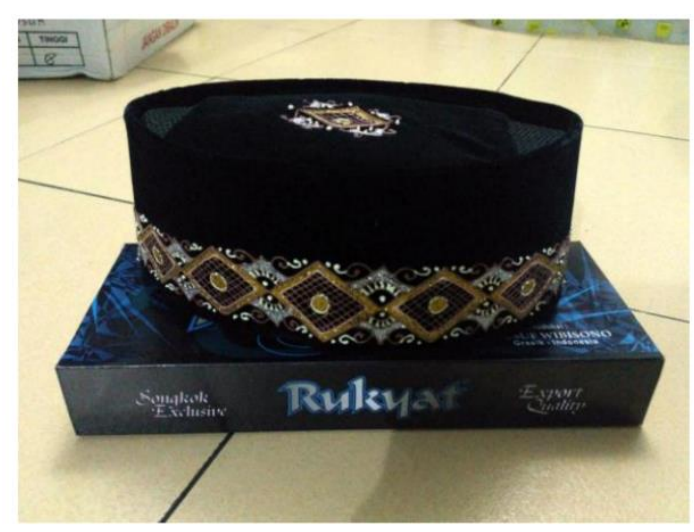

Gambar 1.5 Peci Rukyat (Sumber: Internet) 


\section{PEMBAHASAN}

2.1. Konsep Materi Komunikasi (Ide Besar, Pesan, Isi Materi)

Dalam perancangan kemasan songkok guru ini, konsep desain yang digunakan terbagi atas 2 (dua) bagian konsep, sesuai dengan jenis kemasan yang dirancang. Konsep kemasan premium (produksi terbatas) berkonsep maskulin, dimana menunjukkan sifat laki-laki (berwibawa, gagah dan keras ) sesuai dengan penggunaan dari songkok guru yang hanya digunakan oleh pria dewasa sesuai dengan strata sosialnya. Pada kemasan produksi massal konsep desain yang diterapkan adalah Alami atau nature sesuai dengan sifat dasar dari bahan yang digunakan pada songkok guru yang menggunakan bahan alami (serat pelepah daun lontar). Masing-masing konsep tersebut diterapkan pada rancangan koprehensif kemasan, baik pada kemasan premium yang diproduksi secara terbatas dan kemasan yang diproduksi secara massal.

Merek (Brand), Merek produk tetap di ambil dari nama produk itu sendiri, yaitu Songkok Guru agar orang lebih gampang mengenalinya, bahwa songkok guru ini dulunya merupakan songkok yang dipakai oleh para raja atau petinggi adat pada acara-acara adat sebelum dijadikan oleh-oleh. Pada pembuatan merek ini juga nantinya akan dibuat secara simple dan elegan dengan konsep logo yang terinspirasi dari bentuk huruf aksara lontara yang akan dikombinasikan dengan bentuk garis motif songkok guru yang secara tidak langsung berbentuk huruf S dan $\mathrm{G}$ yang merupakan huruf awalan songkok guru.

Slogan, pada perancangan kemasan ini hal yang ingin ditekankan yaitu songkok guru ini merupakan kerajinan tardisional yang terbuat dari serat lontar khas Kabupaten Takalar yang wajib dibawa pulang jika berkunjung ke Kabupaten Takalar. Dengan begitu, branding yang disampaikan terinspirasi dari semboyan Kabupaten Takalar yaitu "panrannuangku" (bacaan tulisan aksara lontara yang ada pada logo Kabupaten Takalar) yang artinya harapanku atau amanahku. Jadi pada perancangan kemasan produk songkok guru ini, penulis membangun slogan "songkok panrannuangta" dalam bahasa indonesia artinya songkok harapan atau amanah kita dimana merupakan songkok yang harus kita jaga kelestariannya agar tidak termakan oleh zaman, karena songkok ini merupakan warisan leluhur secara turun temurun.

\subsection{Konsep Komunikasi Visual}

Berdasarkan target audiencenya, yaitu orang dewasa sampai orang tua (usia 23-60 tahun), berikut merupakan konsep dan strategi visual berdasarkan analisis yang telah dilakukan sebelumnya.

Tipografi, Pemilihan tipografi yang digunakan ada tiga yaitu tipografi pada merek/logo, tagline/slogan, dan body teks. Pada merek produk akan digunakan Anvyl sesuai hasil analisis yang telah dilakukan, karena font ini sesuai dengan bentuk logogram yang digunakan memilki karakter huruf aksara lontara dan tegas. Font yang digunakan untuk slogan yaitu Melancholight yang merupakan font jenis hand writing font ini memiliki filosofi yang menimbulkan sifat pribadi dan akrab serta akan mewakili konsep desain tradisional. Serta memperindah tampilan visual kemasan. Sedangkan untuk body teks, font yang digunakan adalah Century Gothic karena simple sehingga tidak menyulitkan konsumen pada saat membacanya.

Warna , berdasarkan hasil anaalisis warna yang digunakan yaitu warna pada objek produk songkok guru dan warna daun lontar yang akan digunakan sebagai bahan kemasan. Hitam yang memiliki makna yaitu maskulin, dapat diandalkan, kebijaksanaan, serta kekuatan. Warna ini sesuai dengan target audiencenya yaitu laki-laki (dewasa). Warna kuning keemasan (gold) akan digunakan untuk teks merek produk karena warna ini merupakan salah satu warna yang ada pada produk dan 


\section{imajinaasi}

juga bermakna mahal atau mewah. Pada penggunaan warna body teks, penulis menggunakan warna hitam/putih agar mudah dibaca dan menonjol. Warna ini bermakna kesederhanaan namun gampang/mudah dilihat oleh mata.

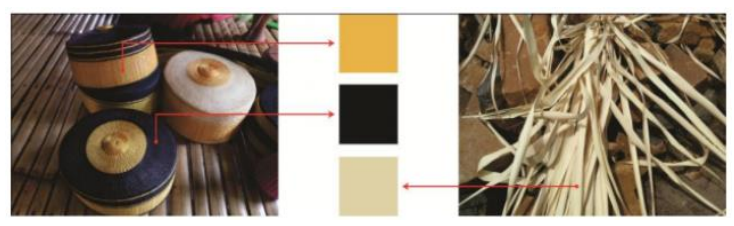

Gambar 2.1 Pengambilan Warna dari Objek (sumber: pribadi)

Bentuk, konsep bentuk kemasan songkok guru tidak memiliki banyak bentuk dikarnakan sifat produk yang kaku dan tidak bisa dilipat (dibentuk). Jadi bentuk kemasan sesuai dengan konsep desain, yaitu pada kemasan produksi terbatas berbentuk kotak persegi karena konsep yang telah di usung yaitu maskulin dimana bentuk persegi itu akan keliatan minimalis dan simple. Selanjutnya pada kemasan produksi massal konsep bentuk yang akan digunakan juga sesuai konsep desainnya yaitu nature, dimana nantinya akan berbentuk tabung. Bentuk tabung dikarenakan bahan yang digunakan adalah anyaman daun lontar yang memiliki sifat fleksibel atau gampang digulung namun nilai tradisionalnya tetap terjaga.

Ilustrasi atau gambar pendukung, digunakan pada kemasan songkok guru berupa ilustrasi yang terkait dengan produk yang menjadi gambar pendukung kemasan. Dipilihlah jenis ilustrasi foto (digital). Ilustrasi tersebut digunakan dengan tujuan menginformasikan produk kepada konsumen, terlebih identitas yang menandakan bahwa produk tersebut merupakan produk lokal dari Kabupaten Takalar.

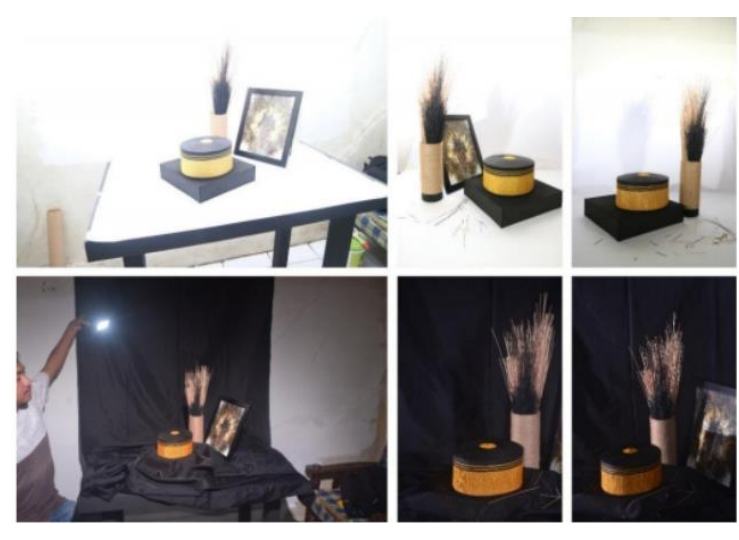

Gambar 2.2 Pemotretan produk

\begin{tabular}{|c|c|c|}
\hline Jenis Informasi & \multicolumn{1}{|c|}{ Keterangan } \\
\hline Fakta Produk & $\begin{array}{l}\text { Terbuat dari serat daun lontar } \\
\text { kering. } \\
\text { Proses pewarnan dan } \\
\text { penganyaman dilakukan } \\
\text { secara tradisional }\end{array}$ \\
\hline Petunjuk & $\begin{array}{l}\text { Petunjuk Cara Perawatan } \\
\text { - Simpan di tempat sejuk dan } \\
\text { kering } \\
\text { - Jangan di cuci } \\
\text { - Jangan dilipat }\end{array}$ \\
\hline Petunjuk & $\begin{array}{l}\text { Petunjuk Penyimpanan } \\
\text { - Simpan ditempat yang sejuk } \\
\text { dan kering } \\
\text { - Dapat di daur ulang } \\
\text { - Dibawa dengan hati-hati } \\
\text { - Keterangan Arah } \\
\text { - Kemasan digunakan } \\
\text { berulang (multi trip) }\end{array}$ \\
\hline $\begin{array}{c}\text { Kode Identifikasi } \\
\text { Produk }\end{array}$ & \begin{tabular}{l} 
Teks rekaan (Dummy Teks) \\
\hline
\end{tabular}
\end{tabular}

Tabel 2.1 Pesan dan simbol pada kemasan

\subsection{Strategi Perancangan}

Didalam suatu perancangan, diperlukan strategi yang dapat mendukung dan memenuhi tujuan dari perancangan tersebut. Dalam perancangan kemasan songkok guru ini, terdapar beberapa strategi yang akan digunakan yaitu :

\subsection{Strategi Kreatif (Pendekatan Sesuai Target Audience)}

\subsubsection{Strategi Visual}

Pada perancangan desain kemasan ini, tampilan visualnya berdasarkan target audiens dan tema yang diambil. Berikut adalah beberapa strategi visual yang dirancang yang sesuai dengan kebutuhan target audience. (1) Agar tampilan visual mudah dimengerti dan 
menggambarkan objek sesuai dengan kenyataan yang ada, maka digunakanlah jenis ilustrasi foto (digital) dengan teknik fotografi. (2) Agar tampilan kemasan terlihat lebih menarik, maka kemasan premium produksi terbatas (Grade A) dan produksi massal (Grade B) dibedakan baik secara bentuk maupun tampilan desain. Untuk kemasan Grade A berbentuk persegi dengan desain yang elegan dan simple. Warna yang digunakanpun disesuaikan dengan warna songkok guru itu sendiri. Sehingga terlihat maskulin sesuai target audience. Sedangkan untuk kemasan Grade B berbentuk sesuai bentuk songkok guru (tabung). Tampilannya pun sangat berbeda dengan kemasan grade A karena terbuat dari bahan alami yaitu daun lontar yang telah dianyam. Untuk warna daunnya tetap menggunakan warna alaminya sehingga menekankan kesan tradisional (nature).

\subsubsection{Manajemen}

Kemasan songkok guru yang telah dirancang nantinya, diharapkan dapat digunakan oleh para pengrajin songkok guru yang ada di Kabupaten Takalar khususnya yang ada didesa Bonto Kassi, Kelompok Melati. Ada beberapa cara yang dapat dilakukan agar produk songkok guru ini dapat dipasarkan yaitu dengan cara menjualnya secara online atau offline, dan mengadakan sosialisasi dengan bekerja sama dengan Dinas Kebudayaan dan Pariwisata Sulawesi Selatan, Dinas Sosial Budaya dan Pariwisata Kabupaten Takalar, Toko OleOle (Takalar dan Makassar) serta ikut serta dalam event-event yang dilakukan oleh daerah maupun diluar daerah (pameran).

Selain melakukan penjualan secara offline maupun online, dan sosialisasi produk songkok guru, media promosi juga sangat menunjang untuk lebih memperkenalkan produk ke khalayak.

\begin{tabular}{|l|l|}
\hline \multicolumn{1}{|c|}{ Media } & \multicolumn{1}{|c|}{ Jalur Distribusi } \\
\hline Poster & $\begin{array}{l}\text { Dipajang di depan pintu masuk } \\
\text { Toko Pusat Ole-Ole (Makassar dan } \\
\text { Takalar) dan Dinas kebudayaan } \\
\text { dan Pariwisata Sulawesi Selatan } \\
\text { serta Dinas Sosial Budaya dan } \\
\text { Pariwisata Kabupaten Takalar }\end{array}$ \\
\hline
\end{tabular}

Tabel 3.2 Distribusi media promosi

\subsubsection{Differensiasi}

Perbedaan mendasar dari kemasan songkok guru ini dengan kemasan songkok yang lainnya yaitu : (1) Kemasannya yang dibedakan menjadi dua yaitu kemasan Premium dan Kemasan produksi massal. Kemasan premium untuk produk songkok guru yang harganya lebih mahal (khusus songkok guru yang memiliki lapisan emas asli). Sedangkan kemasan produksi massal untuk kalangan umum. (2) Bentuk dan desainnya elegan dan tradisional. Untuk kemasan produksi massal terbuat dari bahan alami yang juga bahannya berasal dari daun lontar yang dianyam kemudian dibentuk menjadi kemasan songkok guru kalangan umum. (3) Sangat menampilkan ciri khas budaya kabupaten Takalar yaitu pengrajin anyaman daun lontar dan serat lontar (songkok guru). (4) Kemasannya bisa bertahan lama, tidak mudah rusak. Digunakan untuk menyimpan dan melindungi produk agar lebih awet (multi trip).

\subsection{Strategi Media}

\subsubsection{Jenis Bahan Kemasan}

Jenis kemasan yang dirancang terdiri dari 2 (dua) jenis kemasan yaitu kemasan premium dan kemasan produksi massal, dimana sifat material yang digunakan, juga dikelompokkan menjadi 2 (dua) bagian yaitu material yang 
sifatnya kaku dan fleksibel yang didasarkan pada jenis kemasan yang dirancang.

Melihat dari hal tersebut material yang digunakan dapat ditentukan antara lain : (a) Kemasan Premium (Produksi Terbatas), kertas dupleks dengan ketebalan 210gr, kertas karton, kain bludru. (b) Kemasan Produksi Massal, Menggunakan bahan olahan dalam bentuk anyaman daun lontar kering, Plastik mika, Kertas karton, Kertas samsons, Tali rami.

\subsubsection{Dasar Bentuk Fisik Kemasan}

Dasar bentuk fisik terbagi menjadi dua yaitu : (a) Bentuk Kotak Persegi Berdasarkan konsep yang telah ditentukan bentuk kotak persegi akan mengemas produk songkok guru yang paling mahal (menggunakan benang emas asli) dengan konsep yang elegan atau simple dengan memtimbangkan jenis kertas yang akan digunakan yaitu karton yang sifatnya kaku. (2) Bentuk Tabung Pemilihan bentuk tabung berdasarkan pada bentuk produk yang akan dikemas. Jenis bahan kemasan yang digunakan bersifat fleksibel (mudah digulung) sesuai bentuk songkok guru.

\subsection{Media Pendukung}

Berikut adalah beberapa media pendukung yang digunakan : (1) Tote Bag, Tote bag / tas jinjing digunakan secara praktis sebagai tempat produk songkok guru yang telah dikemas agar lebih aman saat dibawa setelah produk dibeli. Tote bag ini dibuat menjadi 2 jenis ukuran sesuai ukuran kemasan premium dan kemasan yang di produksi secara massal. (2) Hang Tag, Media ini berguna untuk memperkuat merek dagang, dimana hang tag ini akan di pasang pada kemasan yang berbentuk tabung (produksi massal) yang akan di ikat pada tali rami pengunci kemasan yang berukuran $7 \mathrm{~cm}$ x $5 \mathrm{~cm}$ menggunakan jenis kertas karton. (3) Display Produk, Display produk digunakan sebagai tempat penjualan/display produk songkok guru yang telah dikemas dan juga dapat digunakan pada event pameran.. Bahan yang digunakan adalah multipleks dengan menggunakan warna yang elegan.

\subsection{Media Promosi}

Poster digunakan pada saat display karya kemasan, selain itu juga dapat dipasang didepan toko tempat menjual produk songkk guru ini. Poster ini menggunakan bahan jenis Albatros dengan teknik cetak digital printing

\subsection{Proses Kreatif}

\subsubsection{Curah gagasan/ Brainstorming}

Ide perancangan kemasan songkok guru khas Kabupaten Takalar diperoleh dari permasalahan tidak adanya kemasan produk sehingga gampang rusak pada saat di beli atau di distribusikan dalam jumlah banyak kepada konsumen. Selain itu, produk ini bisa dikatakan cukup murah dibanding dengan proses pengerjaan yang memakan waktu kurang lebih sebulan, proses pengerjaan yang terbilang rumit serta kurangnya sarana dan prasarana untuk pembuatan kemasan. Berdasarkan permasalahanpermasalahan tersebut, mendukung untuk melatarbelakangi perancangan kemasan songkok guru yang bertujuan untuk menjaga produk dari kerusakan, agar produk terlihat profesional dan harga bisa lebih tinggi dibandingkan sebelum memiliki kemasan produk. 


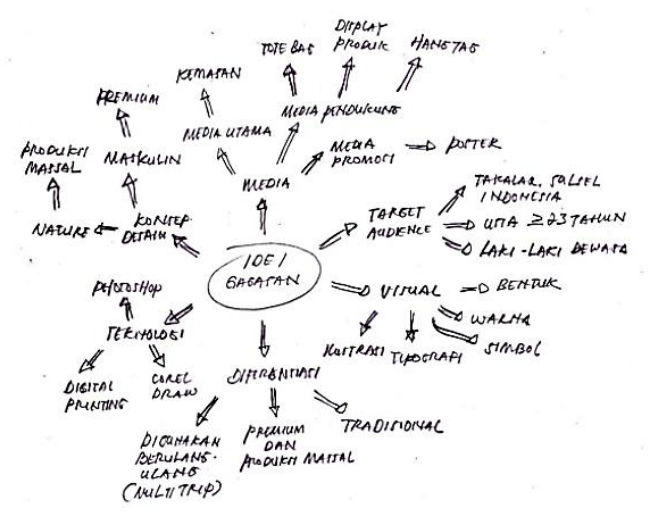

Gambar 3.3 Curah gagasan (brainstorming)

\subsubsection{Pemetaan Gagasan / Mind Mapping}

Sebelum pra perancangan dilakukan terlebih dahulu mengumpulkan gagasan-gagasan yang terdapat disekitar objek perancangan melalui metode Brainstorming. Adapun curah pendapat yang dilakukan untuk mengumpulkan gagasan dan informasi mengenai media utama dan pendukung, konsep dan visual, serta elemen yang dipertimbangkan dalam perancangan ini, yang kemudian dibentuk kedalam sebuah pemetaan gagasan atau mind mapping. Mind mapping digunakan untuk menglompokkan hasil dari curah pendapat yang dilakukan yang dianggap memiliki keterkaitan satu sama lain pada proses perancangan.

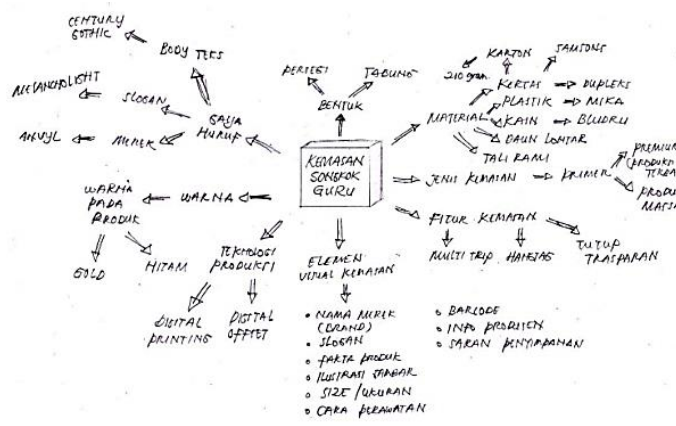

Gambar 3.4 Pemetaan Gagasan / Mind Mapping

\subsubsection{Eksplorasi Visual / Sketching}

Pada tahap ini, dibuat beberapa alternatif sketsa untuk Sketsa Bentuk Kemasan Premium (Produksi Terbatas), Bentuk Kemasan Produksi Massal, Sketsa Logo, media pendukung dan media promosi.

\subsubsection{Digitalisasi}

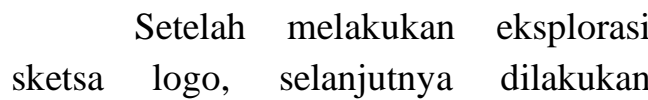
digitalisasi logo dari beberapa sketsa yang telah dibuat untuk menciptakan gambar yang ideal dan sesuai dengan konsep yang telah di usung sebelumnya. Selanjutnya, digitalisasi kemasan produksi massal dibagi kedalam 2 (dua) ukuran kemasan yaitu songkok guru ukuran 5-7 dan ukuran 8-10 bertujuan agar produk yang dikemas tidak memiliki banyak ruang kosong. Sedangkan kemasan premium (produksi terbatas) hanya memiliki satu ukuran saja. Gambar pendukung yang dikerjakan menggunakan teknik fotografi, selanjutnya diolah secara digital di komputer. Hal ini dilakukan untuk mendapatkan kualitas gambar yang stabil (resolusi gambar) dan akurasi warna yang bagus.

Aplikasi yang digunakan dalam proses digitalisasi yaitu corel draw dan photoshop.

\section{KESIMPULAN DAN SARAN}

\subsection{Kesimpulan}

Dari akhir segala rangkaian perancangan kemasan songkok guru Kabupaten Takalar dapat disimpulkan bahwa, dalam mendukung eksistensi produk songkok guru untuk tetap ada dizaman modern seperti sekarang ini, dibutuhkan media yang mampu menunjang produk serta media penunjang lainnya sehingga mengapa media kemasan 
sangat dibutuhkan pada produk ini. Selain menjaga eksistensinya, kemasan ini juga bertujuan agar nilai penjualan lebih tinggi dari sebelumnya yang tidak memiliki kemasan pada saat penjualan. Berdasarkan proses yang telah dilakukan selama perancangan kemasan produk songkok guru, maka dapat ditarik kesimpulan sebagai berikut : (1) Kemasan dibuat dalam 2 konsep yaitu, maskulin untuk kemasan premium (produksi terbatas) dan nature untuk kemasan produksi massal. (2) Dalam proses perancangan kemasan premium ada beberapa kendala terutama dalam hal kerapian. Namum seiring beberapa kali dilakukan percobaan akhirnya dapat menghasilkan sebuah kemasan dengan menggunakan bahan kertas karton sebagai pola kemasan yang berbentuk kotak dan kertas dupleks ketebalan $210 \mathrm{~g}$ sebagai pembungkus (label) kemasan serta menggunakan kain bludru sebagai pelapis didalam kemasan agar produk tidak rusak jika terbentur. (3) Selanjutnya dalam proses pembuatan kemasan produksi massal, langsung menggunakan bahan daun lontar yang merupakan daun dari pelepah lontar itu sendiri sehingga daunnya tidak terbuang begitu saja dan dapat dimanfaatkan sebagai kemasan dari produk tersebut. Daul lontar ini dijadikan sebagai pengalas dan penutup kemasan. Selain menggunakan daun lontar juga dipadukan dengan kertas karton sebagai dinding yang dilapisi kertas samsons sebagai labelnya dan didalamnya juga dilapisi kain bludru agar produk tidak gampang rusak. Sebagai pengunci menggunakan tali rami agar nilai tradisionalnya tetap terjaga. (4) Media pendukung, terdiri dari : Display Product, Tote bag, Hang tag. (5) Media promosi yang dibuat adalah poster dengan menggunakan bahan jenis albatros dengan teknik cetak digital printing yang di tempel pada display product agar orang lebih gampang melihatnya.

\subsection{Saran}

Untuk pemanfaatan lebih lanjut, hasil desain digunakan sebagai kemasan produk songkok guru di Kabupaten Takalar khususnya oleh Kelompok Melati di Desa Bontokassi Kecamatan Galesong Selatan. Pemanfaatan juga diberikan bagi para penggiat perancangan kemasan dan komunikasi visual sebagai salah satu sumber literatur yang relevan dalam merancang kemasan. Segala bentuk kekurangan yang terdapat pada hasil rancangan merupakan keterbatasan selama proses perancangan berlangsung, baik keterbatasan berupa ilmu pengetahuan serta teknologi pendukung yang ada.

\section{DAFTAR PUSTAKA}

Aulia, R. (2017). ANALISIS FAKTORFAKTOR YANG MEMPENGARUHI PRODUKSI PENGRAJIN ANYAMAN SERAT LONTAR SONGKOK GURU DI DESA BONTOKASSI KECAMATAN GALESONG SELATAN KABUPATEN TAKALAR. 1-94. Dipetik Januari 10, 2018, dari http://repositori.uinalauddin.ac.id/5523/1/RISKA\%20AU LIA_opt.pdf

Cenadi, C. S. (2009). PERANAN DESAIN KEMASAN DALAM DUNIA PEMASARAN. $I I(1), 91-103$. Dipetik Januari 9, 2018, dari http://ema606.weblog.esaunggul.ac.id /wpcontent/uploads/sites/186/2015/02/Se minar-Manajemen-Pertemuan-7.pdf

Klimchuk, M. R., \& Krasovec, S. A. (t.thn.). DESAIN KEMASAN "Perencanaan Merek Produk yang Berhasil Mulai dari Konsep sampai Penjualan". Ciracas, Jakarta: Erlangga.

Patria, A. S., \& Mutmaniah , S. (2015). KERAJINAN ANYAM SEBAGAI PELESTARIAN KEARIFAN 
LOKAL. Dimensi, 12(1), 1-10. Dipetik Januari 10, 2018, dari http://download.portalgaruda.org/artic le.php?article $=469463 \& \mathrm{val}=9647 \& \mathrm{tit}$ le=KERAJINAN\%20ANYAM $\% 20 \mathrm{~S}$ EBAGAI\%20PELESTARIAN\%20K EARIFAN\%20LOKAL

Rahmatsyam Lakoro, S. (2002). Studi Komunikasi Visual Pada Kemasan Makanan Ringan. Jurnal Idea. Dipetik Januari 9, 2018, dari http://personal.its.ac.id/files/pub/2002 -ramokRiset\%20Ilustrasi\%20Kemasan\%20$\% 20$ jurnal\%20IDEA.pdf

Said, A. A. (2014). Desain Kemasan. Makassar: Universitas Negeri Makassar.

Sari, N. L. (2013, April). ELEMEN VISUAL KEMASAN SEBAGAI STRATEGI KOMUNIKASI PRODUK. VI, 43-52. Dipetik Maret 2, 2018, dari http://ejournal.uinsuka.ac.id/isoshum/profetik/article/view/1 $175 / 1085$ 